\title{
The French, the British and their Middle Eastern Mandates (1918-1939): Two Political Strategies
}

Les Français, les Britanniques et leurs mandats au Moyen-Orient (1918-1939) : regards croisés sur deux stratégies politiques

\section{Myriam Yakoubi}

\section{OpenEdition}

\section{Journals}

Electronic version

URL: https://journals.openedition.org/rfcb/8787

ISSN: 2429-4373

Publisher

CRECIB - Centre de recherche et d'études en civilisation britannique

Electronic reference

Myriam Yakoubi, "The French, the British and their Middle Eastern Mandates (1918-1939): Two

Political Strategies", Revue Française de Civilisation Britannique [Online], XXVII-1 | 2022, Online since 04

January 2022, connection on 01 February 2022. URL: http://journals.openedition.org/rfcb/8787

This text was automatically generated on 1 February 2022.

\section{cc) (†)}

Revue française de civilisation britannique est mis à disposition selon les termes de la licence Creative Commons Attribution - Pas d'Utilisation Commerciale - Pas de Modification 4.0 International. 


\title{
The French, the British and their Middle Eastern Mandates (1918-1939): Two Political Strategies
}

Les Français, les Britanniques et leurs mandats au Moyen-Orient (1918-1939) : regards croisés sur deux stratégies politiques

\author{
Myriam Yakoubi
}

\section{Introduction}

1 On 1st December 1956, while Britain and France were facing the diplomatic consequences of the Suez Crisis, the French Orientalist Jacques Berque gave his inaugural lecture at the Collège de France, where he held a chair in the social history of contemporary Islam. In his lecture, Berque tackled the long history of the relationship between France and the Arab world. Despite the context, he wanted to believe that the French language and culture would still play a role in the region's future:

Voyez notre langue, notre culture, elles sont aujourd'hui combattues ou soutenues en Orient, à la fois parce qu'elles étaient celles de la bourgeoisie et parce qu'elles sont celles de l'intelligentsia. Langue de la " gauche » et de l'éducation missionnaire [...], véhicule à la fois d'un humanisme aux valeurs reconnues et d'une inquiétude qui le remet en cause, le français et son message ont encore, dans ces pays, un avenir que l'inimitié des adversaires permet seule de mesurer. Adversaires dont peu sont arabes, car le français, j'ose le déclarer même aujourd'hui, reste l'hellénisme des peuples arabes. ${ }^{1}$

Even though Berque does not specify who France's non-Arab opponents in the East could be, the context of the Cold War points to the Soviet Union. He might also have had the United States in mind. Since the end of the First World War, the latter had increasingly looked down on the imperialist powers like Britain and France, which seemed unable to come to terms with a changing global context. By clinging to their imperial possessions, the two countries might have dissuaded colonized countries from siding with the Western bloc. However, and despite the circumstantial alliance of the 
Suez Crisis, the British themselves inevitably come to mind. The linguistic and cultural means through which France maintained a significant influence in the Middle East, which are extolled by Berque, had irritated the British for a long time. The latter had been rather late in understanding the importance of what could be called cultural diplomacy. It was only in the late 1930s, when Lord Lloyd became Chairman of the British Council, that the latter's activities expanded and that cultural diplomacy was recognized as an essential tool for British foreign policy. ${ }^{2}$ The French, by contrast, had been spreading their language and culture in Egypt and the Levant since the second half of the 19th century, especially through missionary and secular education. The French were proud of what they called la France du Levant, a term invented by Parisian publicists to refer to France's historical ties with the Christians of the Eastern Mediterranean and its linguistic and cultural influence. ${ }^{3}$ By stressing France's intellectual legacy in the Levant, Berque may have been willing to implicitly compare it with British interests in the same region, which were strategic and economic. There was indeed a long-standing negative perception of Britons as a materialistic and antiintellectual people among French thinkers. The latter thought that whereas the French wanted to promote idealistic and noble values overseas, the British were only concerned with their economic and financial interests. ${ }^{4}$ Berque seems to have embraced this idealized vision of the French presence in the Middle East and in the excerpt above, he does not mention the fact that the French, like the British, had significant economic stakes in that region. Moreover, the French, had also been politically involved in the affairs of the Ottoman Empire through the Capitulations system $^{5}$ and the significant role played by their Consuls. In his famous book about the Eastern question, Arnold Toynbee explained that networks of consulates, embassies, religious missions and schools constituted a locus of power for both Britain and France and played a central role in the rivalry between the two countries in the Ottoman Empire before the First World War. ${ }^{6}$

Berque's contention that French influence could best be measured by its rivals' hostility shows that European empires assessed their power and influence by comparing themselves with their competitors. It is indeed worth remembering that imperial officials and experts of different countries observed and compared each other's strategies. They also interacted on a regular basis, sometimes to counter each other's power but also sometimes to cooperate. ${ }^{7}$ The shared presence of the French and the British in the Middle East in the interwar years is a case in point. In their recent work about imperial rhetoric in Britain and France, Martin Thomas and Richard Toye have focused on the Middle East because it was in this region that tensions between the two countries ran the highest from the end of the 19th century to $1956 .{ }^{8}$ However, as the French and the British empires in the Middle East became contiguous, both countries became involved in what the authors have coined "co-imperialism", which they define as a collaborative project between several imperial states involving the movement of personnel and the translation of expertise between different imperial systems. ${ }^{9}$ Indeed, Britain and France had to cooperate in order to delineate new borders or to deal with a rising nationalist threat. After the First World War, the two countries were entrusted with mandates of the League of Nations, which were defined as a sacred trust of civilisation, with a duty to turn the former Arab provinces of the defeated Ottoman Empire into modern nation-states. ${ }^{10}$ It was in this new international context marked by the principle of self-determination as defined by the American President 
Woodrow Wilson in 1918 that Syria came under French rule while PalestineTransjordan ${ }^{11}$ and Iraq came as new additions to Britain's empire.

4 Historians working on European nationalism or the making of national identity in Europe have stressed that the latter often stemmed from confrontation and/or comparison with outsiders. ${ }^{12}$ In the colonial context, confrontation with the local populations comes to mind, but closer attention also needs to be paid to the reassertion of distinctive national traits as opposed to those of the European colonial or imperial rival, even in the 19th century. Indeed, the discourse of imperial officials about the nature, interests and strategies of other empires is likely to shed light on their own vision of their power rather than on the object of their discourse.

5 The aim of this article is therefore to examine how, in the Middle East, the French and the British discourses about the two countries' respective political strategies revealed more about their own certainties and doubts as to their ability to rule their mandates, particularly Syria for the French and Iraq and Transjordan for the British. ${ }^{13}$ In their book, Toye and Thomas chose a case study approach which focuses on moments of crisis from the end of the 19th century to the Suez Crisis but the only episode which took place between the two world wars was the 1922 Chanak Crisis. This article, however, intends to study this relationship in the interwar years, after Britain and France came to an agreement about how to share the spoils of war in the Middle East. It seems worth asking how the relationship played out when tensions were only simmering because it was in this relatively peaceful context that most of the interactions between the two countries took place. This article will thus offer some tentative insights into the nature of the Franco-British relationship in the Middle East in the interwar years, especially through the use of the private papers and reports of some of the people on the spot who were involved in managing relations with their imperial counterparts. While the existing scholarship has focused on comparing British and French mandates ${ }^{14}$ or on stressing the intense rivalry between the two imperial powers, ${ }^{15}$ this article will also explore the non-confrontational aspects of the relationship, which may have been somewhat neglected.

It will first dwell on the specificity of British and French interests and strategies in the Middle East before analyzing the mutual suspicions at work in the discourses of the people on the spot. Finally, the article will show that the Franco-British relationship in that region also entailed cooperation and emulation.

\section{French and British interests and strategies in their Middle Eastern mandates}

7 During the war, even though the British committed more troops than the French in the Middle East, both countries fought together against the Ottomans, first during the Gallipoli Campaign in April 1915 and then during the Arab Revolt in 1916 onwards. That same year, Britain and France came to an agreement about the sharing of the Arab provinces of the Ottoman Empire, thus anticipating its defeat. However, the so-called Sykes-Picot agreements, according to which Palestine was to be an international zone in fact a Franco-British condominium - were quickly called into question by the British, who were determined to keep the French as far away from Egypt and the Suez Canal as possible. The 1917 Balfour Declaration, through which the British Government pledged its support to the creation of a Jewish national home in Palestine, was a way for the 
British to renege on their agreement with the French. ${ }^{16}$ In fact, several decisions were renegotiated between Lloyd George and Clemenceau ahead of the 1919 Paris Peace Conference and the French made several concessions in the Middle East. ${ }^{17}$ However, they insisted on controlling the territory which they referred to as "Syria", a loosely defined geographical notion. ${ }^{18}$ Their ambition was to extend the political and cultural influence they already exerted in the Levant further inland. They also claimed this Syrian territory in the name of their long-standing protection of Catholic minorities in the Levant. However, an economic logic was also at work as the territories the French were adamant to control were those where their investments in railways, ports and other industries were concentrated. Finally, for the French, a formal presence in the Levant was also a way to boost their prestige in their North African colonies. Syria was the former seat of the Umayyad Caliphate and in the 19th century, the country had been the centre of an Arab cultural revival. By integrating Syria to its empire, France sought to strengthen what it called its Muslim policy. ${ }^{19}$

The strategy of the French to manage their Syrian mandate was to divide up the territory along ethnic and sectarian lines. As a result, there were five distinct political entities: two states based around the cities of Damascus and Aleppo, Greater Lebanon ${ }^{20}$ with its Christian majority, the autonomous territory of the Alawites, a Shiite sect, in the Latakia area, and the Jebel Druze, in Southern Syria, where the form of Shiite Islam that was practised was peculiar to that region. The French thought that minority communities had to be protected and turned into allies, a strategy which was a legacy of the informal influence they had exerted in the region before the fall of the Ottoman Empire. However, this divide and rule strategy fed Syrian nationalism, which the French constantly underestimated during the mandate, ascribing it to nonrepresentative urban, Western-educated elites. The French were also convinced that any form of political opposition they faced was encouraged by British intrigues.

At the beginning of the mandate, French rule was rather direct and authoritarian. The government was highly centralized around the offices of the High-Commissioner, located in Beirut. There were also delegates controlling the local indigenous governments and French advisers in the various ministries. Moreover, there was a significant French military presence due to a conflict with Kemalist forces over the region of Cilicia, and also to pacify the areas in which there were attempts to resist French rule. The French promoted local political autonomy while resorting to a form of centralized management when it came to the budget and the economy of the mandate as a whole. Despite the integration of what the French called Les États du Levant into their empire, the latter were isolated from a geographical point of view. There was no contiguity between these states and their Algerian colony or the Protectorates of the French in North Africa.

10 The British, on the other hand, already controlled several parts of the Middle East when they were granted mandates in that region. They had occupied Egypt as early as 1882, as the control of the Suez Canal was vital for access to India. The British were also on friendly terms with several chiefs of the Arabian Peninsula and the emirates along the Persian Gulf had been integrated into the informal empire of the Raj for several decades.

11 In 1921, the Colonial Secretary, Winston Churchill, convened a conference in Cairo to organize Britain's new empire in the Middle East. Because of the need to reduce expenses and to adapt to the new international discourse of self-determination, 
Churchill decided to rely on Britain's wartime Arab allies, the Hashemites. This family had rebelled against the Ottomans with the support of Britain and France. The leader of the family and sharif ${ }^{21}$ of Mecca, Hussein, expected to be rewarded with a large independent Arab kingdom after the war. Even though this proved impossible in the light of British and French ambitions in the region, two of Hussein's sons played a prominent role after the war. Faisal, who had set up an Arab administration in Damascus at the end of the war, was toppled by the French in 1920 after the San Remo Conference granted them a mandate in Syria. However, the following year, the British decided to proclaim him King of Iraq in the context of their own mandate. Abdullah, his brother, became the ruler of Transjordan, which was first conceived by the British as a buffer state between Palestine and the Arabian Peninsula. The French in Syria thus found themselves surrounded by British-ruled Palestine, a Hashemite Kingdom and a Hashemite Emirate. The decision to rely on Arab political figures to control their own mandates infuriated the French because the British appeared to be much more liberal than they were. They feared that Faisal's position in particular might boost demands for an Arab national government in Syria. General Gouraux, the first French High Commissioner, warned Churchill that Faisal, like Frankenstein, was a British creature which would ultimately turn against his masters by using nationalism against them. ${ }^{22}$ In this region, the mandates of the League of Nations did not serve the same purposes for Britain and France, nor did they have the same significance. A first glance at the strategies the two countries put in place to rule their mandates also suggests that the two systems were complete opposites: a liberal British model based on indirect rule ${ }^{23}$ and a rather uncompromising French model based on direct control. Officials on both sides often referred to these two different patterns as typical of the two empires. However, such assertions do not stand up to a comparative approach, which reveals specificities but also many similarities. ${ }^{24}$ In the Middle East, the British ruled Palestine directly for almost thirty years because of their dual obligation ${ }^{25}$ to Arabs and Jews whereas in Syria, the French increasingly relied on local elites, a strategy which had been practised for years in Morocco.

Despite such similarities, once the lot of the former Arab provinces of the Ottoman Empire was settled, suspicion pervaded the Franco-British relationship, probably because of the weight of history, as underlined by Toynbee in his Western Question:

One cannot understand-or make allowances for-the postwar relations of the French and British Governments over the 'Eastern Question' unless one realises this tradition of rivalry and its accumulated inheritance of suspicion and resentment. It is a bad mental background for the individuals who have to represent the two countries. ${ }^{26}$

It should not be forgotten that the rivalry between Britain and France in the Middle East predated the negotiations which took place during the First World War and shaped representations of the other on both sides. Episodes such as the 1898 Fashoda Incident were often referred to by British officials during the war. In January 1916, four months before the Sykes-Picot agreements were signed, Gilbert Clayton, who was a member of the Arab Bureau ${ }^{27}$ and who had participated in the Battle of Omdurman with General Kitchener in the Sudan, wrote about Sykes' French counterpart: "Picot is an enthusiast in the Eastern Mediterranean and is one of the Anglophobe school of 1898 and previous". ${ }^{28}$ After the agreement was signed, most of the British officials on the spot resented the concessions that had been made to the French and blamed Sykes who, in his turn, 
complained about the "Fashoda spirit" of his colleagues. ${ }^{29}$ This legacy of suspicion and resentment continued throughout the interwar years.

\section{The "Fashoda spirit": rivalry and mutual suspicions in the interwar years}

The interwar years are part of what historian Elizabeth Monroe coined "Britain's moment in the Middle East". ${ }^{30}$ Between the First World War, after which Russia, Italy and Germany lost their influence in the region, and the moment when international competition resumed with the Cold War, there was a quasi-British hegemony in the Middle East. Aware that their presence in Syria and Lebanon was an obstacle to the complete control of the region by the British, the French often suspected British plots against them, surmising that their counterparts were seeking to use Arab nationalism against them. As Toynbee noted, the French were the most affected by paranoia because they had received the smallest share of the Middle Eastern spoils of war. ${ }^{31}$ The French also resented the fact that the British had used Arab and Jewish nationalism to secure their interests during the war. They thought that by doing so, the British had opened Pandora's box. They anticipated that Arab nationalism was to harm both French and British interests in the near future and the French feared that this phenomenon might spread to North Africa. ${ }^{32}$

One of the first reasons behind the tensions between the French and the British was the assassination attempt on Syria's first French High Commissioner, General Gouraud, in June 1921. The French blamed Syrian nationalists whom they suspected of having fled to Transjordan and they accused Abdullah of sheltering them. As they saw the Amir of Transjordan as a British puppet, the French thought that if those responsible for the assassination attempt were tolerated in Transjordan, it meant that the British were reluctant to extradite them. Yet British records show that the question of Abdullah's entourage was of great concern to the British in the period following the establishment of his administration in Transjordan. Indeed, some of the Arab nationalists who had been part of his brother's Arab administration in his short-lived Kingdom in Syria had joined Abdullah in Transjordan. These men were reluctant to accept British and French rule of the Arab Middle East through the mandates system. Contrary to what the French seem to have believed, the British did not take this matter lightly. In fact, before promoting Abdullah in Transjordan, they had made it clear to him that he had to accept French rule in Syria. Even though the British rejected the accusations of the French on the grounds that the evidence against the Syrian nationalists in Transjordan was not conclusive, ${ }^{33}$ in private, they put tremendous pressure on Abdullah for him to expel these men. The British were indeed worried about the negative influence of these nationalists on Abdullah because they were likely to turn against British interests in Transjordan itself or in neighbouring Palestine. In 1924, Colonel Frederick Peake, who commanded Transjordan's Arab Legion, expressed his frustration with the chaotic situation in Transjordan, which he attributed to Abdullah and his Syrian entourage:

The reason why we cannot get good security, why we cannot arrest and hand over criminals, why the prestige of the Legion is low, why the officers are afraid to act, is the Amir Abdullah and some few Syrian anti-English, anti-French, anti-Jew, protheir-own-pockets-only, officials who up to now have held all the posts of Government. $^{34}$ 
That same year, the British presented Abdullah with an ultimatum: he had to submit to all British wishes, including getting rid of these nationalists, or risk losing his emirate. The following year, in 1925, the British and the French set up extradition agreements between Syria and Transjordan. ${ }^{35}$ This shows that it took the British and the French several years to define borders and conclude transnational legal agreements, the imposition of such norms being one of the distinctive features of colonial rule.

The British were confident that establishing a monarchy in Iraq and an emirate in Transjordan, both with local Arab governments, was the right way to rule their Middle Eastern mandates. They believed that this form of indirect rule would placate nationalists and give more legitimacy to the new political entities. Some of the British officials on the spot were convinced that Arab nationalism and British interests were compatible. For instance, Gertrude Bell, who as Oriental Secretary was a very close adviser to Percy Cox, the British High Commissioner in Iraq, strongly believed in an ideal Anglo-Arab partnership. Bell thought that indirect rule worked best when the personal relationships between British officials and Arab political players were excellent. In 1922, she wrote a letter in which she compared the relationship of Robert de Caix, Gouraud's closest civilian administrator, with the Syrians and the relationship between Percy Cox and the Iraqis:

They [the French] are amazingly out of touch; there isn't the close personal link of acquaintance and knowledge between a man like de Caix and the Syrians that exists between any of our senior (or junior) officials and the native population of Iraq. It begins with us from the top, with Sir Percy and his amazing personal position, and not all the integrity and earnest desire to fulfill the responsibility he has undertaken can help M. de Caix and his like to bridge the void. In the first place none of them talk Arabic - just think what it means when you've got to establish intimate relations through an interpreter. ${ }^{36}$

Bell's words illustrate the confidence of the British who claimed to have a special ability to understand and therefore rule the natives whereas the French only focused on administering territories in an effective way, neglecting personal relationships along the way. However, the belief that the British ruled by the sheer force of personality can easily be debunked. In 1920, following the announcement of the British mandate in Iraq, there had been a tribal revolt which had spread to the whole country before being violently put down by the British. Bell's confidence just two years after this revolt may therefore seem overly optimistic. Even if the situation was now stable in Iraq, it was not so much thanks to the personality of British officers but because the British had co-opted the members of the Arab Sunni elite and convinced them to participate in the new state's institutions. The exclusion of Shiite Muslims and Kurds led to several upheavals during the mandate, and afterwards, but Bell always believed that the difficulties of the French in Syria were much worse and made the British compare favourably. Moreover, her criticism of the fact that French officials in Syria could not speak Arabic is a reminder of the fact that the British often prided themselves on mastering Arabic and on being familiar with the customs of the various communities of the countries they ruled. Bell herself was indeed one of those British officials who had travelled extensively in the Middle East before the outbreak of the war. She spoke Arabic fluently and knew tribal customs. In Syria, it is true that the first years of the mandate were dominated by the willingness to extend the influence of the French language and of Catholicism, which led to a gap between French officials and the Arab and Sunni Muslim elite. However, after the Druze Revolt of 1925 there was a 
significant shift in French policy. From the end of the 1920s onwards, French orientalists were involved in a redefinition of the purposes of the mandate. Louis Massignon, who represented the French Colonial office in the joint ministerial Commission on Muslim Affairs, visited Syria in 1927-1928 and recommended that more attention be paid to Arabic instead of French as the language of emancipation. Massignon also suggested that the French should not exclusively focus on Beirut and Mount Lebanon, where they had strong connections with Catholic elites, but also on Damascus and its Sunni Muslim elites. He also thought that the French needed to come to terms with Syrian nationalism, instead of seeing it as an existential threat. From the early 1930s onwards, thanks to institutions such as the French Institute in Damascus, France promoted a policy which was based on cooperation with Syrian intellectual circles. Technical experts who knew the country and Arabic-speaking orientalists were the agents of that new policy, which greatly differed from the strictly military management of the early years of the mandate ${ }^{37}$ Therefore, Bell was not completely mistaken when she described the French as being out of touch in 1922, but the methods and strategies of the French later evolved, unlike her critique of French rule.

The 1925 Druze Revolt in Syria was indeed a turning point in the history of the Middle Eastern mandates. Despite tensions between the local communities in the Jebel Druze and the French Governor, the High Commissioner, General Sarrail, refused to meet a delegation of representatives who wanted to voice their discontent. An uprising followed, first in the Jebel Druze but which later spread to Damascus, where the nationalists lent their support to the revolt. The French first bombed the Syrian capital in October 1925 and it took them over a year to restore order in the country. This episode fuelled French distrust of the British, whom they suspected of financing and informing the Druzes, Britain's political clients in the decades before the First World War. In A Line in the Sand, James Barr asserts that the British strove to prolong the insurrection. He also rightly underlines the role of the British press, which was highly critical of the way France managed the uprising. ${ }^{38}$ However, as Anne-Lucie ChaigneOudin makes clear, the suspicions of the French also show that they were unable to depart from a colonial logic of rivalry to acknowledge the reality of Syrian nationalist aspirations. ${ }^{39}$

In 1932, the British granted Iraq its formal independence and the country joined the League of Nations. However, two years before, they had concluded a treaty with the Iraqi Prime Minister, a close British ally, which protected their political, economic and strategic interests. Initially, this early Iraqi independence was again seen as a threat by the French in Syria, who feared they might appear as much more conservative than the British. Indeed, Syrian nationalists made the most of the opportunity by using the Iraqi example as an argument in their negotiations with the French, even if they knew that the terms of the Anglo-Iraqi treaty significantly limited Iraqi sovereignty. In 1936, the British also concluded a treaty with Egypt which gave it more autonomy and meant that the British would withdraw their troops from the country, except in the Canal zone. It was also the beginning of the Palestine rebellion, which was to last until 1939. This regional context encouraged the French authorities in Syria to adopt the same strategy as the British and to conclude a treaty to placate Syrian nationalists. In Paris, Leon Blum's new Popular Front government was also intent on reforming and negotiating with the nationalists. At the end of 1936, the terms of a Franco-Syrian treaty were signed along the same lines as the treaty between Britain and Iraq. The 
independence and unity of Syria, which had been the two claims of the nationalists, were granted. There was also a separate treaty signed between France and Lebanon. However, these treaties met the opposition of the military and Catholic circles, which campaigned against the ratification of the treaty by the French Parliament, arguing that the treaties failed to protect religious minorities. This time, British policy in Iraq served as an example not to be followed. Indeed, shortly after Iraq's formal independence, Assyrian Christians had been massacred by an Iraqi General. The French Senate was sensitive to such events and refused to ratify the treaties..$^{40}$

This shows that beyond the discourses which described two very different imperial paradigms, the strategies of the French and the British in the Middle East evolved and could draw inspiration from one another. Moreover, despite their mutual suspicion, the two mandatory powers had to cooperate on several issues.

\section{Beyond rivalry: cooperation, emulation and inspiration}

The military management of their respective mandates brought the British and the French together on a regular basis. In addition to the traditional diplomatic representation of both countries in each other's mandates, there were liaison officers whose duty it was to keep in touch with military authorities. Border issues were particularly sensitive as Syria, Iraq and Transjordan had nomadic populations whose lives were affected by the setting up of modern borders. Both Syria and Transjordan had camel corps (the Contrôle bédouin and the Transjordan Frontier Force) whose officers met on a regular basis. As a result, border posts like Deir Ezzor (between Syria and Iraq) and Suwaida (between Syria and Transjordan) were places where British and French officers came into close personal contact. ${ }^{41}$ There were also aerial liaisons between the only French air force in Syria, the 39th aerial regiment, and the Royal Air Force, whether in Palestine/Transjordan or Iraq. Bi-monthly meetings were organized, during which officers on both sides exchanged flying techniques and practised together. The liaison officers themselves saw these meetings as opportunities to improve relations between the two mandatory powers. ${ }^{42}$ From the mid-1920s onwards, the British and the French signed agreements about the conditions in which the nomadic populations, now identified as exclusively "Syrian" or "Transjordanian", could cross the borders of the newly established states. These agreements formally acknowledged solutions which had first been found by local officers, members of the French Contrôle Bédouin and their British counterparts who were in charge of desert areas. ${ }^{43}$ In the early 1930s, a mixed tribunal with French and British representatives settled cross-border tribal disputes, for example over stolen livestock. This cooperation sometimes led to more personal relationships when officers visited each other, thus initiating a form of trans-imperial sociability. ${ }^{44} \mathrm{All}$ in all, as Martin Thomas has shown, even if the French and the British were inspired by distinctive models of tribal policy Morocco for the French and the North-West frontier of India for the British - both imperial powers considerably disrupted the nomadic populations' way of life, sometimes resorting to violence, sometimes to subsidies or patronage, in order to subdue them. ${ }^{45}$

Air power was the cornerstone of imperial security in Britain's Middle Eastern mandates whereas the French mainly relied on ground troops and only used air power as reinforcement. However, just as the British had done in Iraq in 1920, the French used 
aerial bombings to crush the Druze Revolt in 1925, which shows that mandatory powers could borrow one another's repression techniques. In fact, French officials discussed the advantages and drawbacks of relying on air power as much as the British did. While some wanted to adopt the same tactics, others underlined the difference between the limited French presence in the Levant and the control of the British in the whole Middle East from the Mediterranean to the Persian Gulf, which made the use of air power much more relevant. ${ }^{46}$

In the 1930s, this British network of communication routes in the Middle East, which included air bases, roads and pipelines conveying oil to the Mediterranean coast, was an object of admiration for at least one French observer. Robert Montagne was an orientalist, ethnologist and sociologist who presided the French Institute of Damascus. In 1936, he wrote an article in which he undertook to study British methods in the Middle East. Even though his article coincided with the Anglo-Egyptian Treaty, Montagne thought that the British imperial system in the Middle East was still to be reckoned with. He praised what he saw as a highly effective and pragmatic system which relied on the specific expertise of various men on the ground:

En Orient, la sécurité de l'Empire exige avant tout le maintien de moyens de communication et l'établissement d'une chaîne d'alliances entre les États. Par nature, cette politique voit grand, large et se préoccupe moins de réalisations durables que de combinaisons utiles. Ceux qui la mènent sont des marins, comme au Golfe Persique, des aviateurs en Irak, des spécialistes du désert au Nejd, en Transjordanie, au Sinaï, des diplomates à Bagdad. Tous ont en commun le désir d'utiliser les forces locales sans se laisser prendre par elles. Certes les fonctionnaires britanniques restent longtemps en Orient, mais ils ne prennent pas racine. ${ }^{47}$

Montagne contrasted the British presence in the Middle East with that of the French, who, according to him, could not help but try to win the hearts and minds of the local populations by attempting to develop infrastructure and agriculture. He praised the British tradition of non-interference in native societies, a legacy of the Indian Mutiny. $\mathrm{He}$ also thought that the very limited number of British officials in Iraq and Transjordan was a source of strength and referred to it as "the triumph of discreet organization". ${ }^{48}$ Montagne was aware that in 1936, the British faced significant difficulties in Palestine and in Iraq, where a military coup had taken place. He admitted that the British system was weakened but he nevertheless encouraged the French not to underestimate their counterparts' achievements, which he thought were great indeed.

Montagne's praise of the way in which the British used the local social forces in the countries they administered is not so surprising in the light of his professional background. Before Syria, Montagne had worked with Hubert Lyautey, who had been the first French Résident général in Morocco in 1912. Lyautey became the architect of the French Protectorate in Morocco, where he stayed until his resignation in 1925, except for a short spell as Ministre de la Guerre in 1916-1917. In Morocco, Lyautey became familiar with the tribes and cooperated with local elites, showing great respect for local customs. He believed that the French needed to adapt to the local circumstances of the countries they ruled and advocated a flexible attitude based on cooperation rather than coercion. ${ }^{49}$

Such an approach is very similar to the philosophy of John Bagot Glubb, who commanded Transjordan's Arab Legion, the country's armed forces. Glubb initiated the 
policy of recruiting members of nomadic tribes into desert units to put an end to tribal raids across the borders of the country. Several tribal sheikhs were also integrated into the nascent institutions of the Emirate. Glubb was an admirer of the Bedouins, whom he saw as true and authentic Arabs, and of their way of life and customs, which he thought needed to be preserved. In that respect, his vision was similar to that of Lyautey, who saw the tribal chiefs in the Atlas region of Morocco as the equivalent of the old French nobility descended from feudal times. ${ }^{50} \mathrm{Glubb}$ also wrote that the time he spent with Bedouin tribes reminded him of the Middle Ages. ${ }^{51}$ Both men were also fascinated with the local rulers of the countries which they administered. In their eyes, Transjordan's Hashemite dynasty and the Alaouites in Morocco embodied prestigious lineage, cultural authenticity and a form of benevolent conservatism. Glubb and Lyautey also had in common a professed admiration for the people and the culture of the Arab countries in which they lived. Lyautey emphasized the need for what he called "cette parcelle d'amour sans laquelle il ne se fonde rien de grand" 52 while Glubb wrote in a memorandum: "Without sympathy, understanding is impossible, and no British official should be allowed to serve in the East who does not love the people". ${ }^{53}$ Such similarities in the two men's racial and cultural representations may be accounted for by a common orientalist and religious inspiration. However, these similarities are also a reminder of the fact that colonial discourses and practices circulated from one empire to another and in the case under study, from North Africa to the Middle East. Since Lyautey's work in Morocco predated Glubb's arrival in Transjordan in 1930, the latter may have been inspired by the methods of his French counterpart, as the presence of Lyautey's name in Glubb's private papers testifies. ${ }^{54}$ On the other hand, Lyautey knew of British methods of indirect rule which, in turn, were much older than his own arrival in Morocco. Lyautey wanted to use indirect rule in Morocco, but the French authorities were determined to rule the North African country directly, despite the status of Morocco as a Protectorate. Even though Lyautey left North Africa in 1925, his ideas lived on and were spread in the Levant by men who, like Montagne, had worked with him in Morocco before being sent to Syria. ${ }^{55}$

\section{Conclusion}

After the First World War, the French and the British strove to maintain their interests while having to take into account the principle of self-determination. By creating new Arab governments, it seems that the British adopted the cleverest strategy to prove that they intended to play by the rules of the new global order. On the whole, European diplomats and journalists were more critical of French rule in the Levant than they were of British indirect rule in Iraq and Transjordan. ${ }^{56}$ This led to a complacent British discourse about their ability to rule Arab people in a friendly way. The French, on the other hand, were convinced that the British strategy encouraged Arab nationalism at their expense. French suspicion was probably fed by the fantasies of the British men and at least one woman - on the spot, who often dreamt of Arab unity under a benevolent and discreet British supervision. However, contrary to what the French seem to have believed, there was not one uniform British point of view. In fact, decision-makers in London and Paris were realists and they wanted friendly relations not just in the Middle East but throughout the world. ${ }^{57}$ Moreover, as this article has tried to show, not all the British in the Middle East were blinded by old prejudices 
against the French. Men like Lyautey, Montagne and Glubb had much in common even though they were products of different imperial systems.

Irrespective of these differences, the rise of Arab nationalism in the region as a whole shows that Middle Eastern communities felt that they were under the same imperial yoke. Moreover, the small advantage the British may have had was ruined by their policy in Palestine. It was precisely in order to improve their tarnished image in the Arab world that they pressurized the French into granting Syria and Lebanon their independence during the Second World War. This time, French suspicions were justified whereas in the 1930s, it seems that they were groundless most of the time. ${ }^{58}$

Ultimately, instances of rivalry or cooperation between the British and the French in the Middle East in the interwar years testify to the interconnectedness of colonial empires. The latter should not be considered political entities that were merely juxtaposed but rather ones whose interests sometimes clashed and sometimes overlapped. Despite the rivalry between them and the specificities of their respective imperial strategies, the British and the French shared the same imperial logic that was ultimately defeated by local resistance and a changing global context.

\section{BIBLIOGRAPHY}

Barr, James, A Line in the Sand, The Anglo-French Struggle for the Middle East, 1914-1948 (New York, Norton \& Company, 2011).

Cannadine, David, (ed.), What is History Now? (Basingstoke; New York, Palgrave Macmillan, 2002).

Charle, Christophe, Jeanpierre, Laurent and Renaut, Sophie (eds.), La Vie intellectuelle en France, Vol. 1, Des Lendemains de la Révolution à 1914 (Paris, Éditions du Seuil, 2016).

Chaigne-Oudin, Anne-Lucie, La France et les rivalités occidentales au Levant : Syrie-Liban, 1918-1939

(Paris, L'Harmattan, 2006).

Cloarec, Vincent, "La France du Levant ou la spécificité impériale française au début du XX siècle", Revue française d'histoire d'outre-mer, tome 83, no. 313, 4 trimestre (1996), pp. 3-32.

Colley, Linda, Britons, Forging the Nation 1707-1837 (London, Vintage, 1996).

Dakhli, Leyla, "L'expertise en terrain colonial : les orientalistes et le mandat français en Syrie et au Liban", Matériaux pour l'histoire de notre temps, vol. 99, no. 3 (2010).

Glubb, John Bagot, Britain and the Arabs, A study of Fifty years, 1908 to 1958 (London, Hodder \& Stoughton, 1959).

Hobsbawm, Eric, Nations and Nationalism since 1780, Programme, Myth, Reality (Cambridge, Cambridge University Press, 1990).

Houot, Clothilde, "Securing the Empire after the First World War. Local and Imperial Armed Forces in France's and Great-Britain's Middle Eastern Mandates", paper delivered during the Conference Among Empires: the British Empire in Global Imperial Context, Lignan University, HongKong, 27 May 2015. 
Laurens, Henry, Français et Arabes depuis deux siècles, la « chose franco-arabe » (Paris, Éditions Tallandier, 2012).

Méouchy, Nadine and Sluglett, Peter (eds), British and French Mandates in Comparative Perspectives (Leiden, Brill, 2004).

Monroe, Elizabeth, Britain's Moment in the Middle East, 1914-1956 (London, Chatto \& Windus, 1963).

Montagne, Robert, "La Grande-Bretagne et la protection de la route des Indes", Politique Etrangère, No. 6 (December 1936), pp. 77-87.

Ouahes, Idir, "Une « ceinture » d'espace étatique : le contrôle des Bédouins au début du Mandat Français en Syrie", L'Espace Politique [En ligne], 27 | 2015-3 Consulted 6 December 2019. URL : http://journals.openedition.org/espacepolitique/3695 ; DOI : 10.4000/ espacepolitique.3695

Paris, Timothy, Britain, The Hashemites and Arab Rule (London, Frank Cass, 2003).

Pedersen, Susan, The Guardians: The League of Nations and the Crisis of Empire (Oxford, Oxford University Press, 2015).

Picaudou, Nadine, La Décennie qui ébranla le Moyen-Orient, 1914-1923 (Barcelona, Flammarion, 2017).

Singaravélou, Pierre, (ed.), Les Empires coloniaux, XIX ${ }^{e}-X X^{e}$ siècle (Lonrai, Points, 2013).

Thomas, Martin, "Bedouin Tribes and the Imperial Intelligence Services in Syria, Iraq and Transjordan in the 1920s", Journal of Contemporary History 38, 4 (2003), pp. 539-561.

Thomas, Martin and Toye, Richard, Arguing about Empire, Imperial Rhetoric in Britain and France, 1882-1956 (Oxford, Oxford University Press, 2017).

Toynbee, Arnold, The Western Question in Greece and Turkey, A Study in the Contact of Civilisations (London, Constable, 1922).

Vermeren, Pierre, "Lyautey au Maroc en 1912 : ambitions, jeux de pouvoir parisiens, environnement et enjeux politiques", in Outre-mers, tome 99, no. 376-377 (2012). Cent ans d'histoire des outre-mers. SHOM, 1912-2012. https://www.persee.fr/doc/ outre_1631-0438_2012_num_99_376_4954

\section{NOTES}

1. Quoted in Henry Laurens, Français et Arabes depuis deux siècles, la "chose franco-arabe " (Paris, Éditions Tallandier, 2012), p. 12. "Just think about our language and our culture, which today are being attacked or defended in the East, both because they used to be those of the upper-middle class and because they are now those of the intelligentsia. As the language of the 'Left' and of missionary education [...], French is both a vehicle for humanist principles whose values are universally recognized and for the anxieties which call those ideals into question. As such, the French language and the message it carries still have a future in those countries, which can only be measured by the hostility of our opponents. Few among them are Arabs since, I venture to declare, even today French remains the Hellenism of the Arab peoples."

2. "Lloyd, George Ambrose, first Baron Lloyd", Oxford Dictionary of National Biography, https:// doi.org/10.1093/ref:odnb/34567. Consulted 6 June 2019.

3. Vincent Cloarec, "La France du Levant ou la spécificité impériale française au début du XX siècle", Revue française d'histoire d'outre-mer, tome 83, no. 313, 4 e trimestre, 1996, pp. 3-32.

4. Fabrice Bensimon, "Anglomanie et anglophobie intellectuelles" and "Cordiale mésentente" in Christophe Charle, Laurent Jeanpierre and Sophie Renaut (eds.), La Vie intellectuelle en France, Vol. 1, Des Lendemains de la Révolution à 1914 (Paris, Éditions du Seuil, 2016), p. 322 and pp. 611-612. 
5. The Capitulations were legal agreements which offered European citizens like pilgrims, merchants or missionaries extraterritorial consular jurisdiction in the Ottoman Empire. As the latter grew weaker and weaker, European powers used the Capitulations to offer privileges to local non-Muslim communities, thus strengthening their influence over them. See Nadine Picaudou, La Décennie qui ébranla le Moyen-Orient, 1914-1923 (Barcelona, Flammarion, 2017), p. 23.

6. Arnold Toynbee, The Western Question in Greece and Turkey, A Study in the Contact of Civilisations (London, Constable, 1922), p. 45.

7. Pierre Singaravélou (ed.), Les Empires coloniaux, XIX ${ }^{e}-X X^{e}$ siècle (Lonrai, Points, 2013), pp. 23-24.

8. Martin Thomas and Richard Toye, Arguing about Empire, Imperial Rhetoric in Britain and France, 1882-1956 (Oxford, Oxford University Press, 2017).

9. Ibid., p. 10.

10. About the League of Nations mandate system, see Susan Pedersen, The Guardians: The League of Nations and the Crisis of Empire (Oxford, Oxford University Press, 2015).

11. Even though Transjordan and Palestine were part of the same mandate, in 1923, the British officially recognized Transjordan as an autonomous territory, which was administered separately. Moreover, the British policy of creating a Jewish national home in Palestine was never applied in Transjordan. It was only in 1949, after the integration of the West Bank following the first Arab-Israeli war, that the country officially became known as Jordan.

12. See for example Eric Hobsbawm, Nations and Nationalism since 1780, Programme, Myth, Reality (Cambridge, Cambridge University Press, 1990) and Linda Colley, Britons, Forging the Nation 1707-1837 (London, Vintage, 1996).

13. The British mandate in Palestine is left aside in this article as it can be considered an exception. Contrary to what they did in Iraq and Transjordan, the British did not create a local Arab government in Palestine because of their dual obligation to both Jews and Arabs. The making of a Jewish national home and the rise of two antagonistic nationalisms also make Palestine a unique case. It thus seems more relevant to compare French policy in Syria with that of Britain in Iraq and Transjordan.

14. Nadine Méouchy and Peter Sluglett (eds), British and French Mandates in Comparative Perspectives (Leiden, Brill, 2004).

15. James Barr, A Line in the Sand, The Anglo-French Struggle for the Middle East, 1914-1948 (New York, Norton \& Company, 2011).

16. Mayir Vereté, "The Balfour Declaration and its Makers", Middle Eastern Studies, VI: 1, 1970, pp. 48-76.

17. In the Sykes-Picot agreement, the French had been granted a sphere of influence which spread as far as Mosul but after the war, they gave it up in exchange for shares in the Turkish Petroleum Company, the international consortium which was to exploit Iraqi oil. The British also recognized French claims to Cilicia, a region in Southern Anatolia, which they wanted to integrate into their Syrian mandate but later had to yield to the forces led by Mustafa Kemal, who fought to maintain Cilicia within the borders of present-day Turkey.

18. Concerning the difficulty of defining the borders of Syria, which was sometimes referred to as Greater Syria or through the Arabic term bilad al-sham, see Cyrus Schayegh, The Middle East and the Making of the Modern World (Cambridge, Ma., Harvard University Press, 2017).

19. Picaudou, La Décennie qui ébranla le Moyen-Orient, p. 73.

20. Greater Lebanon became a republic in 1926 and was called Lebanon from that moment onwards.

21. In Arabic, sharif means noble. It is an honorific title given to those who are recognized as descendants of the prophet Muhammad.

22. "Report on Middle East Conference", CAB 24/122, March 12th to 30th 1921, The National Archives, United Kingdom. 
23. The principles of indirect rule were first outlined by Frederic Lugard in The Dual Mandate in Tropical Africa, published in 1922. Lugard, who was High Commissioner and Governor of Nigeria at the beginning of the 20th century, explained how the British relied on indigenous chiefs as intermediaries to administer Northern Nigeria. The use of native political players with a prestigious lineage and embodying authority and tradition had long been practised in India and continued to be used elsewhere, including in the Middle East.

24. Linda Colley, "What is imperial history now?", in David Cannadine (ed.), What is History Now? (Basingstoke \& New York, Palgrave Macmillan, 2002), pp. 134-136.

25. This dual obligation stemmed from the 1917 Balfour Declaration, through which the British Government committed itself to support the creation of a Jewish national home in Palestine while protecting the civil and religious rights of non-Jewish communities. Those principles were integrated in the charter of the League of Nations mandate for Palestine in 1922.

26. Toynbee, Western Question, p. 45.

27. The wartime intelligence agency of the British in Cairo, which oversaw the Arab revolt.

28. Gilbert Clayton, letter to an unknown addressee, 29 January 1916, Gilbert Clayton collection, GB-0033-Sudan Archive, Durham, SAD136/1/197-199.

29. Henry Laurens, "Les crises d'Orient : le Moyen-Orient à partir de 1914", 3rd lecture, Collège de France, 29 November 2017, https://www.college-de-france.fr/site/henry-laurens/ course-2017-11-29-15h00.htm

30. Elizabeth Monroe, Britain's Moment in the Middle East, 1914-1956 (London, Chatto \& Windus, 1963).

31. Toynbee, Western Question, p. 45.

32. Henry Laurens, "Les crises d'Orient", 5th lecture, Collège de France, 6 December 2017, https://www.college-de-france.fr/site/henry-laurens/course-2017-12-13-15h00.htm

33. Timothy Paris, Britain, The Hashemites and Arab Rule (London, Frank Cass, 2003), p. 190.

34. "Extract from report by Lt. Col. F.G. Peake, Officer Commanding the Arab Legion", March 1924, CO 733/ 68, in Alan de Lacy Rush (ed.), Records of the Hashemite Dynasties, Vol 6 (Cambridge, Cambridge Archive Editions, 1995), p. 269.

35. "Report by His Britannic Majesty's Government on the administration under Mandate of Palestine and Transjordan for the Year 1924" in Robert L. Jarman (ed.), Palestine and Transjordan Administration Reports ,1918-1948, Volume 1, 1918-1924 (Oxford, Oxford Archive Editions, 1995), p. 597. 36. Gertrude Bell to her stepmother, Dame Florence Bell, 10 May 1922, Gertrude Bell Archive, Newcastle University, http://gertrudebell.ncl.ac.uk/letter_details.php?letter_id=553

37. Leyla Dakhli, "L'expertise en terrain colonial : les orientalistes et le mandat français en Syrie et au Liban", Matériaux pour l'histoire de notre temps, 99: 3, 2010, pp. 20-27.

38. Barr, Line in the Sand, p. 142.

39. Anne-Lucie Chaigne-Oudin, La France et les rivalités occidentales au Levant : Syrie-Liban, 1918-1939 (Paris, L'Harmattan, 2006), pp. 213-216.

40. Ibid., pp. 223-225.

41. Clothilde Houot, "Securing the Empire after the First World War. Local and Imperial Armed Forces in France's and Great-Britain's Middle Eastern Mandates", paper delivered during the Conference "Among Empires: the British Empire in Global Imperial Context”, Lignan University, Hong-Kong, 27 May 2015. I thank the author for sharing her paper with me.

42. Ibid.

43. Idir Ouhaes, "Une «ceinture" d'espace étatique : le contrôle des Bédouins au début du Mandat Français en Syrie”, L'Espace Politique [En ligne], 27: 3, 2015. Consulted 6 December 2019.

http://journals.openedition.org/espacepolitique/3695 ; DOI : 10.4000/ espacepolitique.3695

44. For instance, see the correspondence of John Bagot Glubb with Syrian frontier officials from 1935 to 1937. Glubb private papers, Box 14, file 7, 1986 accession, Oxford Middle East Centre Archive, Saint Anthony's College, Oxford. 
45. Martin Thomas, "Bedouin Tribes and the Imperial Intelligence Services in Syria, Iraq and Transjordan in the 1920s", Journal of Contemporary History 38: 4, 2003, pp. 539-561.

46. Houot, "Securing the Empire after the First World War".

47. Robert Montagne, "La Grande-Bretagne et la protection de la route des Indes", Politique Etrangère, No. 6 (December 1936), p. 63. "In the East, above everything else, imperial security requires the maintenance of means of communication and the establishment of a chain of alliances between the states. The very nature of this large-scale policy means that it is less concerned with long-lasting achievements than with useful combinations. The men behind it are sailors, like in the Persian Gulf, or pilots like in Iraq. In the Nejd, Transjordan or the Sinai, they are desert experts; in Bagdad, they are diplomats. All these men are united in their desire to use the local communities without being excessively absorbed by them. British civil servants may stay in the East for a long time, but they never put down roots."

48. Ibid., p. 67.

49. Pierre Vermeren, "Lyautey au Maroc en 1912 : ambitions, jeux de pouvoir parisiens, environnement et enjeux politiques", in Outre-mers, tome 99, no.376-377, 2012. Cent ans d'histoire des outre-mers. SHOM, 1912-2012, p.91. https://www.persee.fr/doc/ outre_1631-0438_2012_num_99_376_4954

50. Ibid.

51. John Bagot Glubb, Britain and the Arabs, A study of Fifty years, 1908 to 1958 (London, Hodder \& Stoughton, 1959), pp. 171-172.

52. Quoted in Henry Laurens, "La chose franco-arabe", p. 41. "...this touch of love without which nothing great can be achieved."

53. John Bagot Glubb, "Note on Post War Settlements in the Middle East", 15 November 1942. Glubb private papers, box 54, 2006 accession, Middle East Centre Archive, Saint Anthony's College, Oxford.

54. Glubb private papers, box 24, 2006 accession, Middle East Centre Archive, Saint Anthony's College, Oxford.

55. Edmund Burke III, "A Comparative View of French Native Policy in Morocco and Syria, 1912-1925”, Middle Eastern Studies, 9: 2, 1973, pp. 175-186.

56. Chaigne-Oudin, La France et les rivalités occidentales au Levant, pp. 258-261.

57. Ibid., pp. 261-266.

58. Ibid.

\section{ABSTRACTS}

This paper aims to study the nature of the relationship between the French and the British in the context of their Middle Eastern mandates in the interwar years. More than a mere comparison of the policies and strategies put in place by the two powers to govern their respective mandates, this article intends to be an analysis of the way the British saw the French strategy and vice versa. Such an approach will shed light on the way the British and the French conceived their own policies. The article also dwells on forms of cooperation and similarities in the way the British and the French managed the A mandates of the League of Nations.

Le but de cet article est d'étudier la nature de la relation entre les Français et les Britanniques dans le contexte de leurs mandats au Moyen-Orient dans l'entre-deux-guerres. Plus qu'une 
simple comparaison des politiques et des stratégies mises en place par les deux puissances pour gouverner leurs mandats respectifs, cet article entend étudier le discours des Britanniques sur la stratégie des Français et vice-versa, une approche qui permettra d'éclairer la manière dont Britanniques et Français concevaient leurs propres politiques. L'article se penche également sur les formes de coopération ainsi que les points communs entre les gestions britannique et française des mandats de classe A de la Société des Nations.

\section{INDEX}

Mots-clés: France, Royaume-Uni, Moyen-Orient, mandats, Société des Nations

Keywords: France, United Kingdom, Middle East, mandates, League of Nations

\section{AUTHOR}

\section{MYRIAM YAKOUBI}

CAS (EA 801), Toulouse-Jean Jaurès University.

Myriam Yakoubi is a senior lecturer in British civilisation at Jean Jaurès University in Toulouse. She specializes in the history of the British empire in the Middle East. Her publications include a chapter in Cooperation and Empire: Local Realities of Global Processes (Berghahn Books, 2017) and one in Gertrude Bell and Iraq: A Life and Legacy, (Oxford University Press, 2017). 